\title{
Serum CEA Level Finding
}

National Cancer Institute

\section{Source}

National Cancer Institute. Serum CEA Level Finding. NCI Thesaurus. Code C157427.

A finding that indicates the amount of carcinoembryonic antigen (CEA) in a serum sample. 